\title{
Resistance of Wood Treated with Iron Compounds against Wood-Destroying Decay and Mould Fungi
}

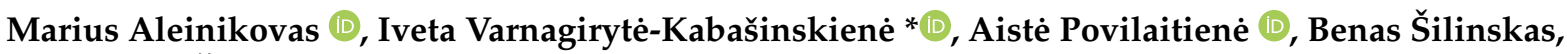 \\ Mindaugas Škèma and Lina Beniušienè
}

check for

updates

Citation: Aleinikovas, M.;

Varnagirytė-Kabašinskienè, I.;

Povilaitienè, A.; Šilinskas, B.; Škèma,

M.; Beniušienè, L. Resistance of Wood

Treated with Iron Compounds against Wood-Destroying Decay and Mould

Fungi. Forests 2021, 12, 645.

https://doi.org/10.3390/f12050645

Academic Editor: Diego Moldes

Moreira

Received: 5 May 2021

Accepted: 17 May 2021

Published: 19 May 2021

Publisher's Note: MDPI stays neutral with regard to jurisdictional claims in published maps and institutional affiliations.

Copyright: (C) 2021 by the authors. Licensee MDPI, Basel, Switzerland. This article is an open access article distributed under the terms and conditions of the Creative Commons Attribution (CC BY) license (https:/ / creativecommons.org/licenses/by/ $4.0 /)$.
Lithuanian Research Centre for Agriculture and Forestry, Institute of Forestry, Liepu str. 1, Girionys, LT-53101 Kaunas District, Lithuania; marius.aleinikovas@lammc.lt (M.A.); aiste.povilaitiene@lammc.lt (A.P.); benas.silinskas@lammc.lt (B.Š.); mindaugas.skema@lammc.lt (M.Š.); lina.beniusiene@lammc.lt (L.B.)

* Correspondence: iveta.kabasinskiene@lammc.lt; Tel.: +370-37-547221

Abstract: Treatment of wood with various physical and chemical factors can change the number of wood parameters, which can also lead to changes in resistance to wood-destroying fungi. This study evaluates the effects of hydrothermal treatments (additives $\mathrm{Fe}_{2} \mathrm{O}_{3}$ or $\mathrm{FeCl}_{3}$ with and without commercial tannins, also without additives and fresh wood) on decay and mould fungi resistance of modified wood of Scots pine (Pinus sylvestris), Norway spruce (Picea abies), Douglas fir (Pseudotsuga menziesii), walnut (Juglans regia), and Norway maple (Acer platanoides). For wood samples, the resistance against wood decay fungi Trametes versicolor (white rot) and Coniophora puteana (brown rot) and the resistance against mould fungi Aspergillus niger and Penicillium sp. were assessed. The study findings showed that wood modified with iron compounds could cause a higher resistance to wood-destroying fungi. The weight losses of the modified and control wood, caused by T. versicolor and C. puteana, differed for coniferous and deciduous: the average weight loss of treated pine, spruce, and fir wood caused by C. puteana was higher than that caused by T. versicolor, while these differences on maple and walnut wood were not significant. The wood hydrothermal treatment with $\mathrm{Fe}_{2} \mathrm{Cl}_{3}$ with and without tannins significantly reduced the weight loss caused by T. versicolor and C. puteana, and the treatment with $\mathrm{Fe}_{2} \mathrm{O}_{3}$ slightly improved the decay resistance. For the wood, hydrothermally modified with $\mathrm{FeCl}_{3}$ and $\mathrm{FeCl}_{3}$ + tannins, the mould area for both tested Aspergillus niger and Penicillium sp. was smallest for the wood of all tested tree species compared to other treatments. A different response was obtained for coniferous and deciduous tree species wood. The spruce wood, followed by fir wood, treated with $\mathrm{FeCl}_{3}$ with and without tannins, was the most resistant against the mould fungi. Relatively low resistance against the mould fungi was fixed for the maple wood treated by various iron compounds, except the treatment with $\mathrm{Fe}_{2} \mathrm{O}_{3}+$ tannins, which gave a very positive response against the Penicillium sp.

Keywords: wood modification; iron oxide; iron salt; tannins; decay test; mould test

\section{Introduction}

Natural wood and wood products with high availability of oxygen, nutrients, and moisture content can be easily degraded by wood-destroying organisms. The microbialdegradable carbohydrates and polar hydroxyls in wood absorb moisture, making wood an attractive material for active biological agents from the environment [1,2]. Over time, this results in decreased wood resistance to various bacteria, moulds, or decaying fungi $[3,4]$, emphasising that fungi are the dominant agents of wood decomposition [5]. Typically, affected wood gradually loses its physical-mechanical characteristics. Despite the fact that it is a very important degradation stage of organic material under natural conditions, it significantly reduces the ability to use the wood for the wood industry, outdoor and indoor constructions, etc. It also significantly shortens the time of wood products use.

Three categories of wood decay, such as brown rot, white rot, and soft rot, are commonly studied [6-8]. Affecting the wood quality, different fungi attack different wood 
components: cellulose, hemicellulose, and lignin. The most common types of wood decay are brown rot and white rot, caused by basidiomycete fungi [9]. For decay tests, Trametes versicolor (L.) Pilat (white rot fungus) and Coniophora puteana (Schumacher) P. Karsten (brown rot fungus) are mainly used. These fungi have different mechanisms of wood degradation: the brown rot fungus primarily attacks cellulose and hemicellulose, while the white rot fungus attacks all of the wood components $[8,10]$.

We could argue that biodegradation of wood with moulds, which are usually fixed on the wood surface, is less dangerous compared to the effects of decaying fungi. However, mould attacks can cause a variety of problems for wooden constructions indoors and outdoors, including the loss of aesthetical view due to the discoloration of wood surfaces and detrimental effects on human health. Individual studies have revealed that mould fungi do not affect the strength properties of wood materials [11]. However, it is important to emphasise that these fungi affect the appearance of wood and can also cause allergic reactions $[12,13]$.

The intensity of mould growth depends on the environmental conditions and on the type of wooden material [14-16]. The growth of mould fungi has been found to be affected by different factors, including oxygen, nutrients, humidity, temperature, light, exposure time, and substrate surface quality (substrate roughness and $\mathrm{pH}$ ), as well as biotic interactions between different cultures [17-21]. It has been shown that mould fungi need an optimal temperature from 22 to $35^{\circ} \mathrm{C}$ and a relative humidity of $71 \%-95 \%$ [22]. Other studies observed that moulds can grow at all temperatures from 0 to $50{ }^{\circ} \mathrm{C}$ and at the relative air humidity of above $80 \%[12,23]$.

Several studies indicated that the prevention of mould growth on wooden materials is an important challenge [24-26]. To increase the resistance of wood and wood products to biological agents, various methods have been recently tested, i.e., the wood is treated with compounds that protect against wood-destroying organisms. However, the use of wood preservatives is often limited due to environmental risks $[27,28]$. Therefore, technological solutions to protect wood using ecological, naturally derived materials are increasingly being tested [29,30]. For example, to protect the wood from fungi or other wood-destroying organisms, essential oils could be used instead of highly toxic traditional wood preservatives [31,32]. Quite widely tested is heat treatment of wood, which has been found to be quite effective against wood decay fungi [33-37]. Data from several studies suggest that thermal modifications change the chemical wood properties and increase wood resistance to decay [38,39].

This study aimed to evaluate the effect of different hydrothermal treatments with additives $\mathrm{Fe}_{2} \mathrm{O}_{3}$ or $\mathrm{FeCl}_{3}$ with and without commercial tannins on wood resistance to decay and mould fungi. Searching for a more reliable wood modification technology, we sampled the wood from different tree species-Pinus sylvestris L., Picea abies (L.) H. Karst., Pseudotsuga menziesii (Mirb.) Franco, Juglans regia L., and Acer platanoides L.—and modified it with iron-containing compounds, which were considered of relatively low toxicity.

\section{Materials and Methods}

\subsection{Wood Treatment}

Five tree species Scots pine (Pinus sylvestris), Norway spruce (Picea abies), Douglas fir (Pseudotsuga menziesii), walnut (Juglans regia), and Norway maple (Acer platanoides) were obtained from a sawmill, and their wood samples were used for the experiment. The sets of 20 wood samples with dimensions of $20 \times 20 \times 30 \mathrm{~mm}$ from each tree species were prepared for the treatment process. The selected wood samples were without knots and free of visible evidence of resins and showed no visual infection by mould, stain, and wood decay fungi.

The prepared wood samples were exposed to the different solvents prepared of $4 \mathrm{~L}$ of distilled water and iron oxide $\left(\mathrm{Fe}_{2} \mathrm{O}_{3}\right)$, iron salt $\left(\mathrm{FeCl}_{3}\right)$, and commercial tannins. In total, there were six treatments: (1) $\mathrm{H}_{2} \mathrm{O}+16 \mathrm{~g} \mathrm{FeCl}_{3}$; (2) $\mathrm{H}_{2} \mathrm{O}+16 \mathrm{~g} \mathrm{FeCl}_{3}+50$ g commercial tannins; (3) $\mathrm{H}_{2} \mathrm{O}+16 \mathrm{~g} \mathrm{Fe}_{2} \mathrm{O}_{3} ;$ (4) $\mathrm{H}_{2} \mathrm{O}+16 \mathrm{~g} \mathrm{Fe} \mathrm{O}_{3}+50 \mathrm{~g}$ commercial tannins; (5) $\mathrm{H}_{2} \mathrm{O}+$ no 
additives, taken as Control 1; and (6) not treated, fresh wood, taken as Control 2. The wood samples were immersed into the solvents and boiled at a constant temperature of $100{ }^{\circ} \mathrm{C}$ in a laboratory pot for $75 \mathrm{~h}$ (hereafter, hydrothermal treatment).

To provide basic information about the treatments, the ratio between the solvent amount and the wood mass was calculated for each tree species. This ratio was 12 for maple wood, 14-15 for walnut, 20 for spruce and fir wood, and 22 for pine wood, irrespective of the treatment. After each hydrothermal treatment, the percentage of dry mass loss was calculated for all tree species and it was as follows: $14 \%-21 \%$ for the treatment with $\mathrm{FeCl}_{3}$; $6 \%-15 \%$ for $\mathrm{FeCl}_{3}+$ tannins; $4 \%-8 \%$ for $\mathrm{Fe}_{2} \mathrm{O}_{3} ; 1 \%-6 \%$ for $\mathrm{Fe}_{2} \mathrm{O}_{3}+$ tannins; and $5 \%-10 \%$ for Control 1. For the evaluation of wood resistance, two controls were used in this study.

After the treatment, the wood samples were removed and dried at the room temperature. Then, the samples were prepared for the fungal decay and mould tests. These tests were carried out at the Laboratory of Entomology and Phytopathology in Forest Institute, Lithuanian Research Centre for Agriculture and Forestry.

\subsection{Fungal Decay Test}

For the fungal decay test, the smaller samples of $20 \times 15 \times 5 \mathrm{~mm}$ were cut from the modified wood samples (hydrothermal treatment with $\mathrm{FeCl}_{3}, \mathrm{FeCl}_{3}+$ tannins, $\mathrm{Fe}_{2} \mathrm{O}_{3}$, $\mathrm{Fe}_{2} \mathrm{O}_{3}+$ tannins) and the controls (Control 1-hydrothermal treatment without additives and Control 2-fresh wood) were taken from pine, spruce, fir, maple, and walnut. In a general case, three smaller samples were cut from each wood sample. For the fungal decay test, 96 wood samples of each tree species, in total 480 samples, were prepared. These samples were dried at $80 \pm 2{ }^{\circ} \mathrm{C}$ for $10 \mathrm{~h}$ until constant weight and weighed with digital scales with $0.01 \mathrm{~g}$ precision (the initial weight in grams, $\mathrm{Wi}$ ).

The decay resistance of wood against white rot (Trametes versicolor) and brown rot (Coniophora puteana) was tested according to the standard EN 113 [40] with some modifications. In our experiment, the wood samples of $20 \times 15 \times 5 \mathrm{~mm}$ instead of $50 \times 25 \times 15 \mathrm{~mm}$, as given in the standard EN 113, were used; the time of the fungal test was 12 weeks instead of 16 weeks; and Petri dishes of $90 \mathrm{~mm}$ diameter instead of 1 L Kolle's flasks were used for the wood exposure.

Fungal cultures were obtained from Westerdijk Fungal Biodiversity Institute (The Netherlands). The culture of T. versicolor was grown on $3.7 \%$ malt extract agar medium, and the culture of C. puteana was grown on $3.7 \%$ potato dextrose extract agar medium. The Petri dishes (diameter $90 \mathrm{~mm}$ ) were filled with $15 \mathrm{~mL}$ of the sterile culture medium $\left(121 \pm 1{ }^{\circ} \mathrm{C}\right.$ for $\left.30 \mathrm{~min}\right)$ and incubated with a piece of mycelium at a temperature of $24{ }^{\circ} \mathrm{C}$ and relative humidity of $75 \%$ for one week. In total, 120 Petri dishes with fungal cultures were prepared. After inoculation, sterilised samples (after autoclaving at $105 \pm 2{ }^{\circ} \mathrm{C}$ for $30 \mathrm{~min}$ ) were placed into the Petri dishes. In each Petri dish, four samples were placed. The wood samples were left in contact with the fungus at a temperature of $24{ }^{\circ} \mathrm{C}$ and relative humidity of $70 \%$ in an incubator chamber for 12 weeks. After this time, the samples were removed from the Petri dish and cleaned of the fungal mycelia. Then, the samples were dried at $80 \pm 2{ }^{\circ} \mathrm{C}$ for $10 \mathrm{~h}$ and weighed again (final weight in grams, $W f$ ) to calculate the percentage of weight loss.

The susceptibility of wood samples to fungi attack was evaluated by the percentage of weight loss $(W L)$, calculated according to the Formula (1) [41].

$$
W L(\%)=\{(W i-W f) / W i\} \times 100
$$

where $W L$ is the weight loss in percent; $W i$ is the initial weight in grams; and $W f$ is the final weight in grams.

\subsection{Mould Test}

For the mould test, 48 samples from each tree species (in total, 240 wood samples) of $30 \times 20 \times 7 \mathrm{~mm}$ were prepared. The anti-mould resistance of the wood was tested according to the European Standard EN 15457 [42] with some modifications in the sterilisation 
process and the shape of the samples. All wood samples were sterilised (autoclaving at $105 \pm 2{ }^{\circ} \mathrm{C}$ for $30 \mathrm{~min}$ ) and dried at a temperature of $80 \pm 2{ }^{\circ} \mathrm{C}$ for $10 \mathrm{~h}$ until constant weight. The sterilised samples were placed into the Petri dishes (diameter $90 \mathrm{~mm}$ ) with malt extract agar medium and inoculated with spore suspension, prepared as a mixture containing two mould fungi: Aspergillus niger Tiegh. and Penicillium Link sp. Three samples were placed per one Petri dish. The spore suspension was made using well sporulating cultures on agar dishes. A total of $15 \mathrm{~mL}$ of sterile water was added to each agar dish with fungal cultures. A bacteria loop was used to loosen the spores from the mycelium/agar. An equal amount of suspension from two mould fungi was mixed by adding $100 \mathrm{~mL}$ of sterile water, totalling $130 \mathrm{~mL}$ of suspension. Wood samples were covered by spore suspension $(0.4 \mathrm{~mL}$ per each sample), containing two mould fungi in a concentration of $10^{6}$ spore $\mathrm{mL}^{-1}$. In total, about $100 \mathrm{~mL}-130 \mathrm{~mL}$ of the spore suspension was applied to all 240 wood samples.

Subsequently, the wood samples were left in contact with the mould fungus at a temperature of $24 \pm 2{ }^{\circ} \mathrm{C}$ and relative humidity of $85 \%-90 \%$ in an incubator chamber for 28 days. During the exposure period, mould growth on the sample top-side $(30 \times 20 \mathrm{~mm})$ was evaluated visually once per week. The development of mould growth on the surface of the wood samples was assessed using the rating scheme described in the Standard EN 15457 [42]. This scheme is based on the percentage of the surface covered with mould fungi. The rating ranged from 0 to 4 , and the percentage area for each rating level is presented in Table 1. The individual mould species on the wood surface were identified visually. For later double checking of the registered mould rating, images of the wood samples were taken every week.

Table 1. Rating scheme for determination of mould growth (according to the EN 15457 [42]).

\begin{tabular}{cr}
\hline Rating Level & Percentage Area of Disfigurements \\
\hline 0 & No growth on the surface of the sample \\
\hline 1 & Up to $10 \%$ growth on the surface of the sample \\
\hline 2 & More than $10 \%$ up to $30 \%$ growth on the surface of the sample \\
\hline 3 & More than $30 \%$ up to $50 \%$ growth on the surface of the sample \\
\hline 4 & More than $50 \%$ up to $100 \%$ growth on the surface of the sample \\
\hline
\end{tabular}

\subsection{Statistical Analyses}

To determine the significant differences of wood weight loss and mould growth area between different wood treatments, ANOVA and Tukey's Studentized Range (HSD) test were used. The different letters next to the mean values show statistically significant differences at $p<0.05$ between the treatments. The obtained data were analysed using the statistical package SAS 9.4 (SAS Institute Inc., Wake County, NC, USA).

\section{Results}

\subsection{Weight Loss of Modified Wood Caused by White and Brown Rot Fungi}

During the decay test, all wood samples were covered by white rot fungi Trametes versicolor and brown rot fungi Coniophora puteana mycelia. The weight losses of the modified and control wood, caused by T. versicolor and C. puteana, differed for coniferous and deciduous wood (Table 2; Figure 1). The average weight loss of treated pine, spruce, and fir wood, caused by C. puteana, was higher than that caused by T. versicolor. However, the differences between these fungi on maple and walnut wood were not significant. A possible explanation for this might be that fungus $T$. versicolor is more common on deciduous trees than on conifers in natural conditions. 
Table 2. Mean (standard error) weight losses of wood samples after exposure (12 weeks) to decay fungi Trametes versicolor and Coniophora puteana. Different letters given next to the mean value show statistically significant differences for each fungus within each tree species between different treatments at $p<0.05(n=8)$.

\begin{tabular}{|c|c|c|c|c|c|}
\hline \multirow{2}{*}{$\begin{array}{c}\text { Tree } \\
\text { Species }\end{array}$} & \multirow{3}{*}{$\begin{array}{c}\text { Treatment } \\
\mathrm{FeCl}_{3}\end{array}$} & \multicolumn{4}{|c|}{ Weight Loss Due to Fungi Effect (\%) } \\
\hline & & \multicolumn{2}{|c|}{ Trametes versicolor } & \multicolumn{2}{|c|}{ Coniophora puteana } \\
\hline \multirow{6}{*}{ Pine } & & $4.37(0.47)$ & $\mathrm{b}$ & $14.75(2.76)$ & $\mathrm{d}$ \\
\hline & $\mathrm{FeCl}_{3}+$ tannins & $3.95(0.47)$ & $\mathrm{b}$ & $25.43(2.05)$ & c \\
\hline & $\mathrm{Fe}_{2} \mathrm{O}_{3}$ & $3.58(0.66)$ & $\mathrm{b}$ & $42.29(1.15)$ & $\mathrm{ab}$ \\
\hline & $\mathrm{Fe}_{2} \mathrm{O}_{3}+$ tannins & $11.84(0.63)$ & $\mathrm{a}$ & $35.94(1.70)$ & $\mathrm{b}$ \\
\hline & Control $1 *$ & $16.39(2.11)$ & $\mathrm{a}$ & $39.41(0.87)$ & $\mathrm{ab}$ \\
\hline & Control 2* & $5.70(1.57)$ & $\mathrm{b}$ & $44.68(2.40)$ & a \\
\hline \multirow{6}{*}{ Spruce } & $\mathrm{FeCl}_{3}$ & $3.17(0.52)$ & $\mathrm{cd}$ & $15.35(2.11)$ & d \\
\hline & $\mathrm{FeCl}_{3}+$ tannins & $4.17(0.24)$ & $\mathrm{bc}$ & $16.61(1.74)$ & $\mathrm{cd}$ \\
\hline & $\mathrm{Fe}_{2} \mathrm{O}_{3}$ & $3.94(0.95)$ & $\mathrm{cd}$ & $31.29(2.78)$ & $\mathrm{b}$ \\
\hline & $\mathrm{Fe}_{2} \mathrm{O}_{3}+$ tannins & $11.32(0.77)$ & $\mathrm{a}$ & $35.55(3.94)$ & $\mathrm{b}$ \\
\hline & Control 1 & $7.60(1.55)$ & $\mathrm{b}$ & $29.56(4.43)$ & $\mathrm{bc}$ \\
\hline & Control 2 & $0.45(0.14)$ & $\mathrm{d}$ & $57.02(3.22)$ & a \\
\hline \multirow{6}{*}{ Fir } & $\mathrm{FeCl}_{3}$ & $3.59(0.37)$ & $a b$ & $19.44(2.93)$ & $\mathrm{bc}$ \\
\hline & $\mathrm{FeCl}_{3}+$ tannins & $1.46(0.19)$ & c & $14.68(0.71)$ & c \\
\hline & $\mathrm{Fe}_{2} \mathrm{O}_{3}$ & $2.75(0.53)$ & $\mathrm{bc}$ & $32.54(3.91)$ & $a b$ \\
\hline & $\mathrm{Fe}_{2} \mathrm{O}_{3}+$ tannins & $1.21(0.31)$ & c & $21.37(2.34)$ & $\mathrm{bc}$ \\
\hline & Control 1 & $4.02(0.48)$ & $a b$ & $31.74(1.30)$ & $a b$ \\
\hline & Control 2 & $4.78(0.55)$ & a & $38.70(5.52)$ & a \\
\hline \multirow{6}{*}{ Maple } & $\mathrm{FeCl}_{3}$ & $17.36(1.74)$ & $\mathrm{cd}$ & $15.94(1.48)$ & $\mathrm{b}$ \\
\hline & $\mathrm{FeCl}_{3}+$ tannins & $15.49(0.59)$ & $\mathrm{d}$ & $18.64(1.56)$ & $\mathrm{ab}$ \\
\hline & $\mathrm{Fe}_{2} \mathrm{O}_{3}$ & $35.13(5.89)$ & $a b$ & $29.69(3.34)$ & a \\
\hline & $\mathrm{Fe}_{2} \mathrm{O}_{3}+$ tannins & $31.04(2.74)$ & bc & $21.70(1.82)$ & $\mathrm{ab}$ \\
\hline & Control 1 & $48.10(4.94)$ & $\mathrm{a}$ & $26.28(3.21)$ & $a b$ \\
\hline & Control 2 & $43.49(3.20)$ & $a b$ & $26.70(5.35)$ & $a b$ \\
\hline \multirow{6}{*}{ Walnut } & $\mathrm{FeCl}_{3}$ & $15.07(0.54)$ & $\mathrm{cd}$ & $18.22(1.68)$ & $\mathrm{b}$ \\
\hline & $\mathrm{FeCl}_{3}+$ tannins & $11.61(0.83)$ & $\mathrm{d}$ & $19.19(1.56)$ & $\mathrm{b}$ \\
\hline & $\mathrm{Fe}_{2} \mathrm{O}_{3}$ & $25.05(2.00)$ & $\mathrm{a}$ & $30.76(0.96)$ & $\mathrm{a}$ \\
\hline & $\mathrm{Fe}_{2} \mathrm{O}_{3}+$ tannins & $17.80(2.16)$ & $\mathrm{bc}$ & $23.97(4.75)$ & $\mathrm{ab}$ \\
\hline & Control 1 & $24.14(0.90)$ & a & $27.77(2.28)$ & $\mathrm{ab}$ \\
\hline & Control 2 & $22.16(0.31)$ & $a b$ & $20.69(3.11)$ & $\mathrm{ab}$ \\
\hline
\end{tabular}

* Control 1 is the hydrothermal wood treatment with no additives; Control 2 is fresh wood, without treatment.

The highest weight loss of the coniferous (pine and spruce) wood, caused by the white rot fungus T. versicolor, was found for the wood treatment with $\mathrm{Fe}_{2} \mathrm{O}_{3}+$ tannins and without additives (Control 1) (Table 2). The hydrothermal treatments with $\mathrm{Fe}_{2} \mathrm{O}_{3}$, $\mathrm{FeCl}_{3}$ with and without tannins, and the fresh wood (untreated wood; Control 2) showed a similar response to T. versicolor: the weight loss of pine wood amounted to $3.6 \%-4.4 \%$ and for spruce wood-3.9\%-4.2\% (except for Control 2). For fir and maple wood, the highest weight loss caused by T. versicolor was obtained for both Control 1 and Control 2, followed by the treatment $\mathrm{FeCl}_{3}$ for fir wood and $\mathrm{Fe}_{2} \mathrm{O}_{3}$ with and without tannins for 
maple (Table 2). For walnut wood, the weight loss for the treatments $\mathrm{Fe}_{2} \mathrm{O}_{3}$, Control 1 and Control 2 ranged between 22.2 and $25.1 \%$, while it was lower for other treatments: $\mathrm{Fe}_{2} \mathrm{O}_{3}+$ tannins $(17.8 \%), \mathrm{FeCl}_{3}(15.1 \%)$, and $\mathrm{FeCl}_{3}+$ tannins $(11.6 \%)$. The data showed that significantly lower values of weight loss were obtained for the wood samples treated with $\mathrm{FeCl}_{3}$ with and without tannins.
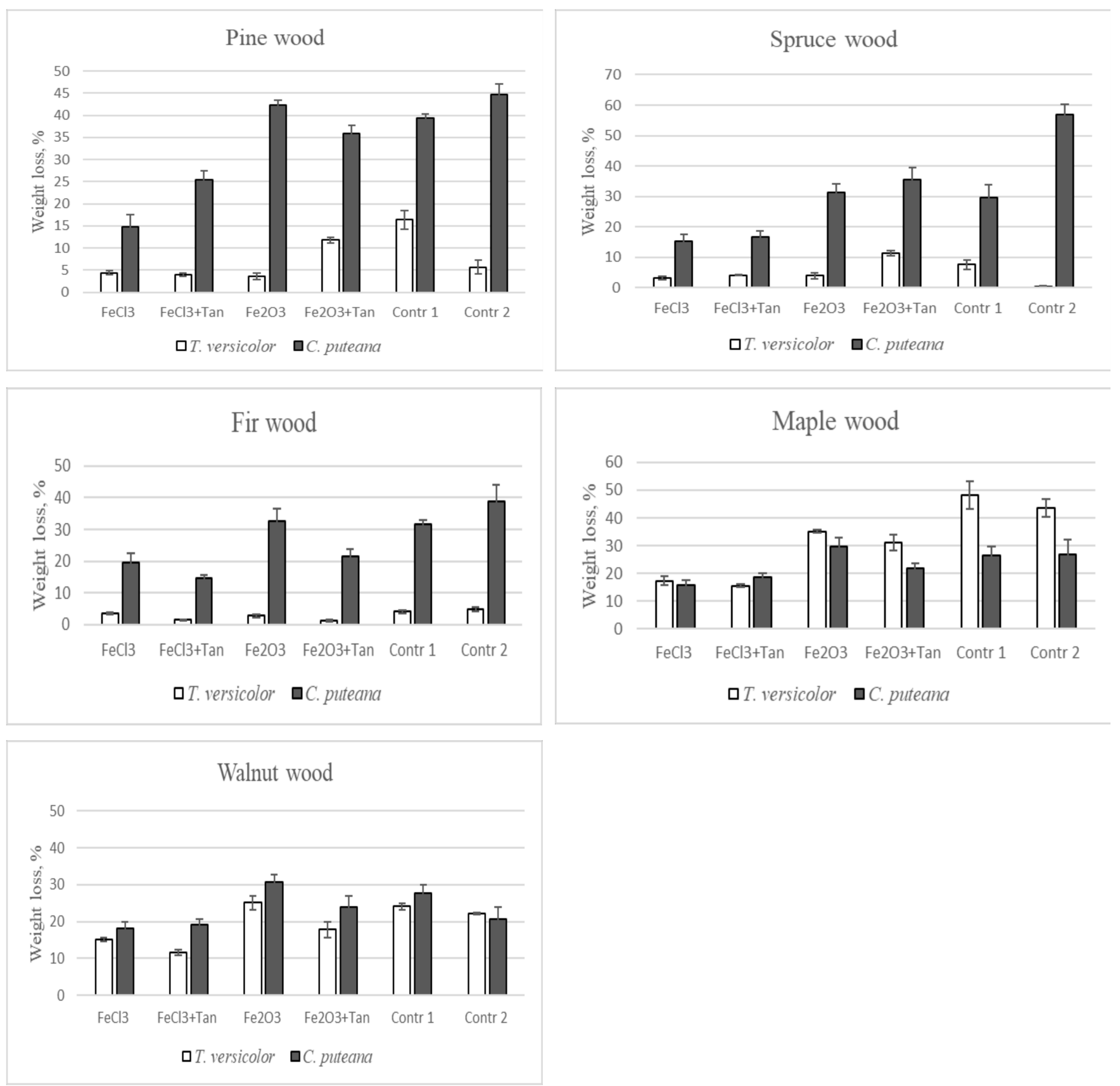

Figure 1. Mean weight loss of wood samples from pine, spruce, fir, maple, and walnut exposed to decay fungi T. versicolor and C. puteana for 12 weeks. Bars show standard error of the mean.

Similarly, as in the case of T. versicolor, the hydrothermal treatments with $\mathrm{FeCl}_{3}$ with and without tannins significantly decreased the weight loss of the coniferous tree species (pine, spruce, and fir) and deciduous (maple and walnut) wood caused by the brown rot fungus C. puteana (Table 2). In this case, the average weight losses of modified wood were $14.8 \%$ and $25.4 \%$ for pine, respectively, for the treatments with $\mathrm{FeCl}_{3}$ and $\mathrm{FeCl}_{3}+$ tannins; 
$15.4 \%$ and $16.6 \%$ for spruce; $19.4 \%$ and $14.7 \%$ for fir; $15.9 \%$ and $18.6 \%$ for maple; and $18.2 \%$ and $19.2 \%$ for walnut wood.

The mean weight losses in the pine wood samples exposed to decay fungi varied in a range from $3.6 \%\left(\mathrm{Fe}_{2} \mathrm{O}_{3}\right)$ to $16.4 \%$ (Control 1) caused by T. versicolor and from $14.8 \%\left(\mathrm{FeCl}_{3}\right)$ to $44.7 \%$ (Control 1) caused by C. puteana (Figure 1). The mean weight losses in the spruce wood samples exposed to decay fungi varied in a range from $0.5 \%$ (Control 2) to $11.3 \%$ $\left(\mathrm{Fe}_{2} \mathrm{O}_{3}+\right.$ tannins) caused by $\mathrm{T}$. versicolor and from $15.4 \%\left(\mathrm{FeCl}_{3}\right)$ to $57.0 \%(\mathrm{Control} 2)$ caused by C. puteana (Figure 1). As an example, the spruce wood samples exposed to brown rot fungus $C$. puteana for treatments with $\mathrm{FeCl}_{3}$ and fresh wood (Control 2) are presented in Figure 2.

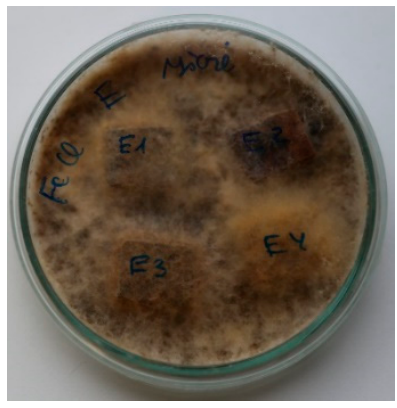

(A)

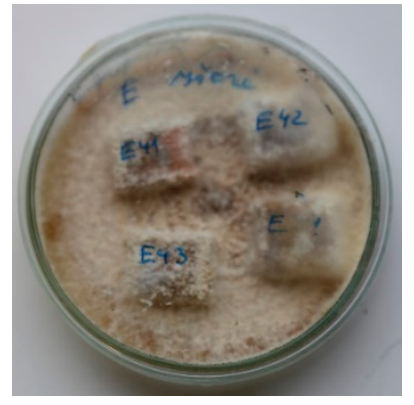

(B)

Figure 2. Examples of spruce wood samples exposed to brown rot fungus C. puteana after treatment with $\mathrm{FeCl}_{3}$ (A) and on fresh wood Control 2 (B) after 12 weeks (Photos: Aistė Povilaitienè).

For the fir wood exposed to T. versicolor, the lowest weight losses were obtained for the treatments with $\mathrm{Fe}_{2} \mathrm{O}_{3}+$ tannins $(1.2 \%)$ and $\mathrm{FeCl}_{3}+$ tannins (1.5\%). While for the fir wood exposed to C. puteana, the lowest weight loss was obtained for the treatment with $\mathrm{FeCl}_{3}+$ tannins $(14.7 \%)$ (Figure 2).

Maple wood samples treated with $\mathrm{Fe}_{2} \mathrm{O}_{3}$ with and without tannins were not as resistant to decay fungi as the wood treated with $\mathrm{FeCl}_{3}$ with and without tannins. The mean weight losses in the maple wood exposed to decay fungus T. versicolor varied in a range from $15.5 \%\left(\mathrm{FeCl}_{3}+\right.$ tannins) to $48.1 \%$ (Control 1 ) and from $15.9 \%\left(\mathrm{FeCl}_{3}\right)$ to $29.7 \%$ $\left(\mathrm{Fe}_{2} \mathrm{O}_{3}\right)$ when caused by $\mathrm{C}$. puteana (Figure 1). As an example, the maple wood exposed to white rot fungus T.versicolor for treatments with $\mathrm{FeCl}_{3}$ and fresh wood (Control 2) is given in Figure 3.

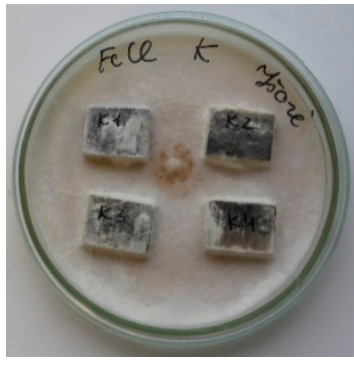

(A)

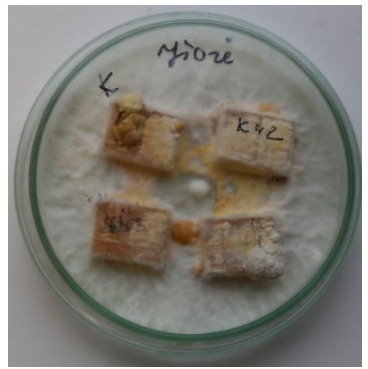

(B)

Figure 3. Examples of maple wood samples exposed to white rot fungus T. versicolor after treatment with $\mathrm{FeCl}_{3}$ (A) and on fresh wood Control 2 (B) after 12 weeks (Photos: Aistè Povilaitienè).

The lowest weight loss of the walnut wood, exposed to T. versicolor, was observed in the treatment with $\mathrm{FeCl}_{3}+$ tannins (Figure 1). For fir wood samples, the lowest weight loss was in the treatments with $\mathrm{FeCl}_{3}$ and $\mathrm{FeCl}_{3}+$ tannins (18.2\% and $19.2 \%$, respectively) caused by C. puteana. 


\subsection{Wood Response to Mould Test}

The two moulds Aspergillus niger and Penicillium sp., used as a mixture, were tested on wood of different tree species. Growth activity of moulds on pine and maple wood, taking one example from coniferous and one example from deciduous species, are given in Figure 4. During the mould test, two fungal species were obtained on wood. In most cases, the Aspergillus niger was the dominating species, possibly because this species is able to adhere more strongly to the wood surface than Penicillium sp. [43].

\section{Treatment}

$\mathrm{FeCl}_{3}$

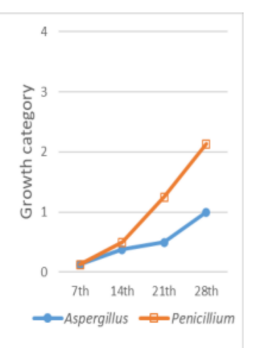

$\mathrm{FeCl}_{3}+$ tannins
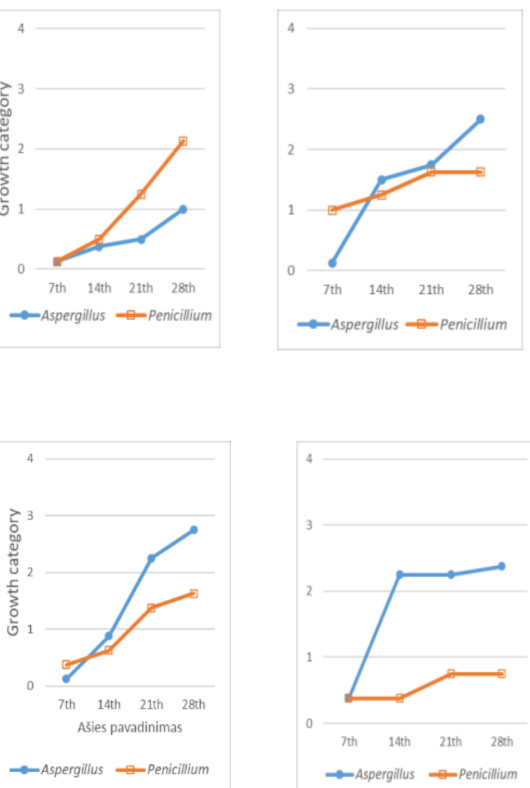

$\mathrm{Fe}_{2} \mathrm{O}_{3}$

$\mathrm{Fe}_{2} \mathrm{O}_{3}+$ tannins

Control 1

Pine wood

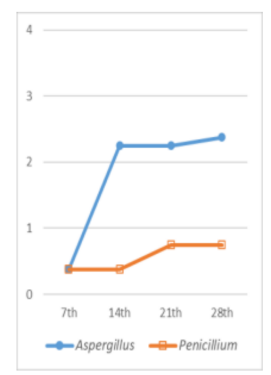

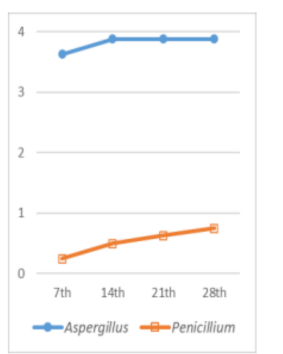

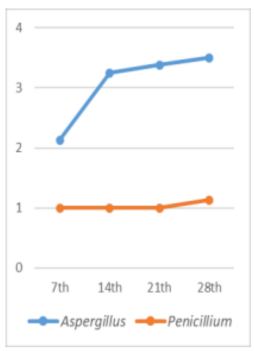

Maple wood
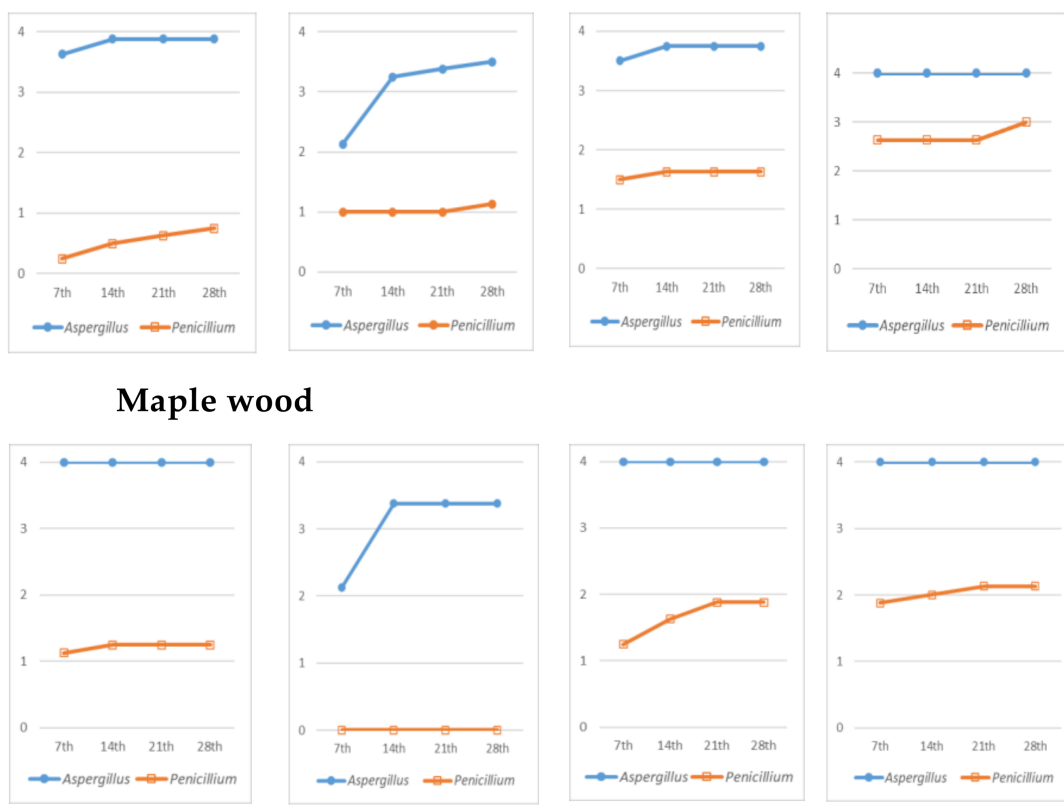

Figure 4. Growth activity of moulds Aspergillus niger and Penicillium sp. on pine and maple wood samples from the 7th to 28th day $(n=8)$. Note: the wood samples were exposed to the suspension made from a mixture containing the two fungi.

For the wood, hydrothermally modified with $\mathrm{FeCl}_{3}$ and $\mathrm{FeCl}_{3}+$ tannins, the mould area for both Aspergillus niger and Penicillium sp. was smallest for all tested tree species wood (Table 3). The mould Aspergillus niger area on wood treated with $\mathrm{FeCl}_{3}$ was 2.2-2.3 times (maple wood), 5.5-8.8-fold (pine wood), and 14.8-16.7-fold (walnut wood) to 24.7-30.8-fold (fir wood) smaller than on wood treated without additives (Control 1) or on fresh wood (Control 2). No active growth of the Aspergillus niger was fixed on spruce wood modified with $\mathrm{FeCl}_{3}$.

The growth area of the mould Aspergillus niger on wood treated with $\mathrm{Fe}_{2} \mathrm{O}_{3}$ with and without tannins was slightly smaller than that of the controls (Table 3). For the treatment with $\mathrm{Fe}_{2} \mathrm{O}_{3}+$ tannins, the growth area of the Aspergillus niger was 1.5-2.0 times smaller than Control 1 for all species. While the growth area of the Aspergillus niger for the $\mathrm{Fe}_{2} \mathrm{O}_{3}$ treatment did not differ from Control 1 for all wood samples, except for fir wood (the difference was 2.6 times). In comparison with the fresh wood (Control 2), the growth area of Aspergillus niger was smaller for wood treated with $\mathrm{Fe}_{2} \mathrm{O}_{3}+$ tannins but no effect was fixed for the wood treated with pure $\mathrm{Fe}_{2} \mathrm{O}_{3}$.

The Penicillium sp. did not grow on spruce and fir wood treated with $\mathrm{FeCl}_{3}$ (Table 3). For wood treated with $\mathrm{FeCl}_{3}+$ tannins, the smallest area of the Penicillium sp. was fixed on fir wood, which differed by almost 26 times when compared to that of Control 1 and Control 2. After the exposure period of 28 days, the Penicillium sp. growth area on pine, 
maple, and spruce wood treated with $\mathrm{FeCl}_{3}+$ tannins was 2.8-6.7 times smaller than the controls.

Table 3. The mean mould growth area (\%) on wood samples and mean mould rating after 28 days exposure $(n=8)$. Note: the wood samples were exposed to the suspension made from a mixture containing the two fungi.

\begin{tabular}{|c|c|c|c|c|c|c|}
\hline \multirow{2}{*}{$\begin{array}{c}\text { Tree } \\
\text { Species }\end{array}$} & \multirow{2}{*}{ Treatment } & \multicolumn{2}{|c|}{ Aspergillus niger } & \multicolumn{2}{|c|}{ Penicillium sp. } & \multirow{2}{*}{$\begin{array}{c}\text { Mean Mould } \\
\text { Rating } * * *\end{array}$} \\
\hline & & Mean & Range (SE) ** & Mean & Range (SE) & \\
\hline \multirow{6}{*}{ Pine } & $\mathrm{FeCl}_{3}$ & 10.6 & $0-30(4.1)$ & 33.8 & $0-80(11.0)$ & 2.5 \\
\hline & $\mathrm{FeCl}_{3}+$ tannins & 38.1 & 5-90(11.7) & 16.8 & $3-50(5.8)$ & 2.9 \\
\hline & $\mathrm{Fe}_{2} \mathrm{O}_{3}$ & 86.3 & $40-100(7.3)$ & 4.5 & $0-20(2.3)$ & 3.9 \\
\hline & $\mathrm{Fe}_{2} \mathrm{O}_{3}+$ tannins & 63.1 & $40-95(7.9)$ & 8.8 & $0-20(2.3)$ & 4.0 \\
\hline & Control $1 *$ & 93.8 & $85-100(2.1)$ & 16.3 & $5-30(3.2)$ & 4.0 \\
\hline & Control 2* & 58.8 & $40-70(3.5)$ & 46.3 & $10-70(6.8)$ & 4.0 \\
\hline \multirow{6}{*}{ Spruce } & $\mathrm{FeCl}_{3}$ & 0.0 & 0 & 0.0 & 0 & 0.0 \\
\hline & $\mathrm{FeCl}_{3}+$ tannins & 6.3 & $0-15(1.8)$ & 4.6 & $0-10(1.3)$ & 1.5 \\
\hline & $\mathrm{Fe}_{2} \mathrm{O}_{3}$ & 75.0 & $20-100(8.7)$ & 11.9 & $0-20(2.8)$ & 3.8 \\
\hline & $\mathrm{Fe}_{2} \mathrm{O}_{3}+$ tannins & 60.6 & $30-100(9.3)$ & 10.8 & $1-20(2.3)$ & 3.5 \\
\hline & Control 1 & 91.9 & $80-100(2.5)$ & 22.5 & $5-40(4.4)$ & 4.0 \\
\hline & Control 2 & 75.0 & $50-90(5.4)$ & 31.3 & $10-60(5.8)$ & 4.0 \\
\hline \multirow{6}{*}{ Fir } & $\mathrm{FeCl}_{3}$ & 2.9 & $0-5(0.9)$ & 0.0 & 0.00 & 0.6 \\
\hline & $\mathrm{FeCl}_{3}+$ tannins & 5.9 & $1-15(1.6)$ & 0.4 & $0-3(0.4)$ & 1.1 \\
\hline & $\mathrm{Fe}_{2} \mathrm{O}_{3}$ & 34.0 & $15-70(7.2)$ & 3.6 & $0-10(1.5)$ & 2.9 \\
\hline & $\mathrm{Fe}_{2} \mathrm{O}_{3}+$ tannins & 47.5 & $20-80(8.4)$ & 8.1 & $5-10(0.9)$ & 3.3 \\
\hline & Control 1 & 88.8 & $60-100(4.7)$ & 6.9 & $0-20(2.8)$ & 4.0 \\
\hline & Control 2 & 71.3 & $30-90(7.4)$ & 9.8 & $3-20(2.2)$ & 3.9 \\
\hline \multirow{6}{*}{ Maple } & $\mathrm{FeCl}_{3}$ & 40.6 & $5-70(8.9)$ & 21.3 & $0-80(9.0)$ & 3.1 \\
\hline & $\mathrm{FeCl}_{3}+$ tannins & 36.9 & 5-90(11.5) & 7.5 & $0-25(3.5)$ & 2.6 \\
\hline & $\mathrm{Fe}_{2} \mathrm{O}_{3}$ & 96.3 & $80-100(2.6)$ & 13.1 & $5-30(3.8)$ & 4.0 \\
\hline & $\mathrm{Fe}_{2} \mathrm{O}_{3}+$ tannins & 58.8 & 30-90(7.2) & 0.0 & 0.00 & 3.4 \\
\hline & Control 1 & 91.9 & $80-100(3.3)$ & 21.9 & $5-50(5.0)$ & 4.0 \\
\hline & Control 2 & 90.6 & $80-100(2.0)$ & 27.5 & $5-50(5.2)$ & 4.0 \\
\hline \multirow{6}{*}{ Walnut } & $\mathrm{FeCl}_{3}$ & 5.9 & $0-20(2.5)$ & 11.3 & $0-20(2.8)$ & 1.6 \\
\hline & $\mathrm{FeCl}_{3}+$ tannins & 26.9 & 5-100(10.9) & 6.9 & $0-20(3.0)$ & 2.4 \\
\hline & $\mathrm{Fe}_{2} \mathrm{O}_{3}$ & 72.5 & $60-90(4.5)$ & 18.8 & $0-50(6.6)$ & 4.0 \\
\hline & $\mathrm{Fe}_{2} \mathrm{O}_{3}+$ tannins & 43.8 & $5-100(12.3)$ & 2.3 & $0-10(1.3)$ & 2.6 \\
\hline & Control 1 & 86.9 & $70-100(3.3)$ & 10.0 & $0-25(2.8)$ & 4.0 \\
\hline & Control 2 & 98.1 & $90-100(1.3)$ & 3.9 & $0-10(1.1)$ & 4.0 \\
\hline
\end{tabular}

* Control 1 is the hydrothermal wood treatment with no additives; Control 2 is fresh wood, without treatment. ** range (SE), where range is the values from the minimum to maximum; SE is standard error of the mean. *** mean mould rating was calculated averaging the rating levels of 8 wood samples for different tree species per each treatment.

The growth area of Penicillium sp. was 3.6 times smaller on pine wood treated with $\mathrm{Fe}_{2} \mathrm{O}_{3}$ than that of Control 1 and 1.7-1.9 times smaller on spruce, fir, and maple wood (Table 3). For the treatment with $\mathrm{Fe}_{2} \mathrm{O}_{3}+$ tannins, the growth area of Penicillium sp. on pine and spruce wood was 1.9-2.1 times and on walnut wood 4.4 times smaller than that of 
Control 1. The growth area of Penicillium sp. was 10.3 times smaller on pine wood treated with $\mathrm{Fe}_{2} \mathrm{O}_{3}$ than that of Control 2 and 2.1-2.7 times smaller on spruce, fir, and maple wood. For the treatment with $\mathrm{Fe}_{2} \mathrm{O}_{3}+$ tannins, the growth area of Penicillium sp. was from 1.2 (fir wood) to 5.3 (pine wood) times smaller than that of Control 2. The Penicillium sp. did not grow on the maple wood treated with $\mathrm{Fe}_{2} \mathrm{O}_{3}+$ tannins.

Mould growth was defined by five mould growth categories, and the mean of the evaluations after 28 days of exposure are given in Table 3 . The highest mould rating (3.8-4.0) was obtained for the treatment with $\mathrm{Fe}_{2} \mathrm{O}_{3}$ (except fir wood) and the control wood samples (treated without additives-Control 1 and fresh wood-Control 2) of all studied tree species. Fir wood had generally the lowest mould rating for the treatment with $\mathrm{Fe}_{2} \mathrm{O}_{3}$ with and without tannins. Overall, the lowest mould rating was recorded for the pine, spruce, fir, maple, and walnut wood treated with $\mathrm{FeCl}_{3}$, and a lower mould rating was recorded for the wood treated with $\mathrm{FeCl}_{3}$ together with tannins.

The species wood resistance against Aspergillus niger in accordance with different treatments can be shown in the following order, from the highest to lowest growth area: (1) for the $\mathrm{FeCl}_{3}$ with and without tannins - spruce (the highest resistant) < fir < walnut $<$ pine $<$ maple (the lowest resistance); (2) for the $\mathrm{Fe}_{2} \mathrm{O}_{3}$ - fir $<$ walnut $=$ spruce $<$ pine $<$ maple; and (3) no significant differences in wood resistance among tree species for the $\mathrm{Fe}_{2} \mathrm{O}_{3}+$ tannins and both controls were found. The order of species wood resistance against Penicillium sp. in accordance with different treatments was different: (1) for both $\mathrm{FeCl}_{3}$ treatments-spruce $=$ fir $<$ walnut $<$ maple $<$ pine; $(2)$ for the $\mathrm{Fe}_{2} \mathrm{O}_{3}$ - pine $=$ fir $<$ spruce $=$ maple $<$ walnut; and (3) for the $\mathrm{Fe}_{2} \mathrm{O}_{3}+$ tannins - maple $<$ walnut $<$ pine $=$ fir $=$ spruce.

Overall, after four weeks, the surfaces of the treated wood samples were fully covered by mycelia of both mould species (Figure 5A, pine wood chosen as an example). Only spruce wood samples treated with $\mathrm{FeCl}_{3}$ remained the most resistant to both mould species (Figure 5B). The maple wood samples treated with $\mathrm{Fe}_{2} \mathrm{O}_{3}+$ tannins were highly resistant to the Penicillium sp. but were highly covered by Apergillus niger (Figure 5C).

\begin{tabular}{|l|l|l|}
\hline $\begin{array}{l}\text { (A) Pine wood samples: } \\
\mathrm{P} 1-\mathrm{P} 2 \text {-treatment } \mathrm{Fe}_{2} \mathrm{O}_{3} ; \\
\mathrm{C} 1-\mathrm{Control} \mathrm{1}\end{array}$ & $\begin{array}{l}\text { (B) Spruce wood samples: } \\
\mathrm{S} 1-\mathrm{S} 2 \text {-treatment } \mathrm{FeCl} ; \\
\mathrm{C} 1-\mathrm{Control} \mathrm{1}\end{array}$ \\
\hline
\end{tabular}

Figure 5. Examples of mould growth on pine (A), spruce (B), and maple (C) wood samples after the treatments with $\mathrm{Fe}_{2} \mathrm{O}_{3}$, $\mathrm{FeCl}_{3}$, and $\mathrm{Fe}_{2} \mathrm{O}_{3}+$ tannins, respectively, and Control 1 (A,B) and Control 2 (C) exposed in each Petri dish for 28 days after inoculation. Note: the wood samples were exposed to the suspension made from a mixture containing the two fungi.

\section{Discussion}

The present study was designed to determine the effect of different hydrothermal treatments $\left(\mathrm{Fe}_{2} \mathrm{O}_{3}, \mathrm{Fe}_{2} \mathrm{O}_{3}+\right.$ tannins, $\mathrm{FeCl}_{3}, \mathrm{FeCl}_{3}+$ tannins, including Control 1 or the treatment without additives and Control 2 or the fresh wood) on wood resistance to decay (white rot fungus Trametes versicolor; brown rot fungus Coniophora puteana) and mould fungi (Aspergillus niger and Penicillium sp.). The response of modified wood samples from five different tree species_-pine, spruce, fir, maple, and walnut—was tested. Previous studies show that wood modification affects the basic wood properties, such as dimensional 
stability, hardness, durability, and UV stability [44]. Several studies also indicated the higher resistance of modified wood against the wood-destroying fungi [45,46].

The current study found that the hydrothermal treatment with various Fe compounds caused the increased anti-decay resistance of the modified wood samples. Overall, the white rot fungus (T. versicolor) caused lower weight loss than the brown rot fungus (C. puteana), except for the maple wood. The stronger positive effect was obtained for brown $\operatorname{rot}$ C. puteana than white rot T. versicolor. Previous studies showed weak or no improvement of the resistance against $T$. versicolor when the wood of pine (Pinus radiata; Pinus sylvestris), spruce, fir, and ash trees were thermally treated [35,47,48]. For example, the study by Sivrikaya et al. [48] showed that the weight loss for thermally treated spruce and ash wood at a $210{ }^{\circ} \mathrm{C}$ temperature was higher than $5 \%$ due to the white rot $T$. versicolor, but the weight loss was lower than $2 \%$ due to brown rot C. puteana. The higher resistance against brown $\operatorname{rot} C$. puteana than that of white rot $T$. versicolor for the thermally treated wood was obtained by Tjeerdsma et al. [35]. Interesting findings were concluded by Leithoff and Peek [49], who described the optimal thermal regimes that are necessary for obtaining the significant resistance against the white $\operatorname{rot} T$. versicolor and brown $\operatorname{rot} C$. puteana, which were, respectively, the wood exposure at a $220^{\circ} \mathrm{C}$ temperature for $120 \mathrm{~min}$ and at $200{ }^{\circ} \mathrm{C}$ for $60 \mathrm{~min}$. Ayata et al. [50] defined that the heat treatment can be used effectively against fungal attack for Scots pine, oak, and beech wood, identifying lower weight losses at a higher intensity of the heat treatment. Yalcin and Sahin [51] also concluded that thermally treated wood was more resistant to both brown and white rot fungi.

In our study, we used the basic decay test with the evaluation of weight loss as the measure of decay. This is one of the most common methods to measure wood degradation in laboratory studies because the wood cell wall components are converted to $\mathrm{CO}_{2}$ by the fungus [52]. Furthermore, the wood resistance against wood-destroying fungi could be evaluated additionally by including the strength loss indicator and biochemical changes in the wood [53]. Otherwise, the mentioned study found a direct relation between wood strength and weight losses. Therefore, it is highly possible that the use of additional methods could only confirm the results obtained in our study.

In this study, the response to the tests of wood-destroying and mould fungi showed the complex effect of heat and iron compounds $\left(\mathrm{Fe}_{2} \mathrm{O}_{3}, \mathrm{FeCl}_{3}\right)$ with or without commercial tannins, but the effect of a single treatment factor could not be determined. As noted by Ohno et al. [54], the treatment of wood with metals was only partially effective in combating soft rot and brown rot fungus, such as Fibroporia radiculosa (Peck) Parmasto, detoxifying copper compounds to form oxalates. A similar fungi response to metal-treated wood was found by Gadd [55]. The content of compounds such as tannins in wood was also related to the susceptibility to mould of different species [56-61]. This was best illustrated by the differences obtained in heartwood to sapwood, i.e., if the heartwood contained high levels of extractives and reduced nutrient levels, the susceptibility to biodegradation was directly affected $[56,62,63]$. In a broader perspective, heat treatment induces significant degradation of amorphous polysaccharides, which occurs at the cell membrane, and the hygroscopicity of the wood decreases [37]. Therefore, the weight loss correlates with the changes in chemical composition of the thermally treated wood. If the content of available nutrients decreased, the resistance against the fungi increased [37]. As Hill [7] showed, the brown rot fungi are related to the removal of the polysaccharide components and white rot fungi degrade both lignin and polysaccharides.

The most important finding of our study was the increase in wood resistance of all studied tree species wood due to the impact of hydrothermal treatment with $\mathrm{FeCl}_{3}$ compounds. The treatments with $\mathrm{FeCl}_{3}$ with and without tannins significantly decreased the weight loss of the coniferous and deciduous wood caused by the white rot T. versicolor and brown rot C. puteana. Similar results were obtained after the mould test, i.e., in comparison to the treated (without additives) and untreated (fresh wood) control, the mould area for Aspergillus niger and Penicillium sp., tested as a mixture containing the two fungi, was smallest on wood treated with $\mathrm{FeCl}_{3}$ and $\mathrm{FeCl}_{3}+$ tannins for all tree species. 
A similar finding was also reported by Råberg et al. [1], who indicated that the toxic or inhibiting substances affect fungal survival and spread in the wood; therefore, the changing nutrient status of the wood during the successive stages of decay should be estimated.

As the natural durability of the wood varies between wood species and is explained mainly by the composition and amount of wood extractives, the better result in our study was obtained for the treated wood when additional commercial tannins were added. This, to some extent, accords with the finding that trees with high content of extractives, mainly tannins and flavonoids, are more resistant against fungi [64].

As mentioned earlier in the text, hydrothermal modification changes the chemical wood structure, making the modified wood more resistant to decay. In order to have a more accurate response, it would be appropriate to study the chemical composition of the wood (cellulose, hemicellulose, lignin, etc.) after hydrothermal treatment with various iron compounds, together with the tests of the wood resistance caused by wood-destroying fungi. Similar tests can be performed with other tree species or by modifying the wood using other metals, such as those with antimicrobial activity.

\section{Conclusions}

This study was set out to evaluate the effect of different hydrothermal treatments $\left(\mathrm{Fe}_{2} \mathrm{O}_{3}\right.$ or $\mathrm{FeCl}_{3}$ with and without commercial tannins) on Scots pine (Pinus sylvestris), Norway spruce (Picea abies), Douglas fir (Pseudotsuga menziesii), walnut (Juglans regia), and Norway maple (Acer platanoides) wood resistance to white-rot fungus Trametes versicolor and brown rot fungus Coniophora puteana and two moulds Aspergillus niger and Penicillium sp., used as a mixture of two mould fungi. The results showed a positive response of the treated wood to different tests of wood-destroying fungi. The best obtained treatment technology included more aggressive $\mathrm{FeCl}_{3}$ compounds, and, while less effectively, yet still significantly, the wood resistance against these fungi was increased when the wood was treated with $\mathrm{Fe}_{2} \mathrm{O}_{3}$ together with tannins.

The wood modified with iron compounds caused a higher resistance to wood-destroying fungi. The weight losses of the modified and control wood, caused by T. versicolor and C. puteana, differed for coniferous and deciduous: the average weight loss of treated pine, spruce, and fir wood caused by C. puteana was higher than that by T. versicolor, while these differences on maple and walnut wood were insignificant. The wood hydrothermal treatment with $\mathrm{Fe}_{2} \mathrm{Cl}_{3}$ with and without tannins significantly reduced the weight loss caused by T. versicolor and C. puteana, and the treatment with $\mathrm{Fe}_{2} \mathrm{O}_{3}$ slightly improved the decay resistance.

For the wood, hydrothermally modified with the pure $\mathrm{FeCl}_{3}$ and with $\mathrm{FeCl}_{3}$ applied together with tannins, the mould area for both Aspergillus niger and Penicillium sp. was the smallest for all tested tree species compared to other treatments. The spruce wood, followed by fir wood, treated with $\mathrm{FeCl}_{3}$ with and without tannins, was the most resistant against the mould fungi. Relatively low resistance against the mould fungi was fixed for the maple wood treated by various iron compounds, except the treatment with $\mathrm{Fe}_{2} \mathrm{O}_{3}$ together with tannins, which gave a very positive response against the Penicillium sp.

Author Contributions: Conceptualization, M.A., I.V.-K. and A.P.; methodology, A.P. and M.Š.; software, B.Š.; formal analysis, I.V.-K., A.P. and B.Š.; investigation, A.P.; writing-original draft preparation, I.V.-K., A.P. and B.Š.; writing-review and editing, M.A., M.Š. and L.B.; visualization, I.V.-K.; supervision, M.A.; All authors have read and agreed to the published version of the manuscript.

Funding: This project received funding from the European Regional Development Fund (project No 01.2.2-LMT-K-718-01-0021) under grant agreement with the Research Council of Lithuania (LMTLT).

Acknowledgments: The authors thank Milda Pukalskienė and Antanas Baltrušaitis for their contribution to the development of a wood modification technology process and valuable comments.

Conflicts of Interest: The authors declare no conflict of interest. 


\section{References}

1. Råberg, U.; Edlund, M.L.; Terziev, N.; Land, C.J. Testing and evaluation of natural durability of wood in above ground conditions in Europe-An overview. J. Wood Sci. 2005, 51, 429-440. [CrossRef]

2. Heseltine, E.; Rosen, J. World Health Organisation Guidelines for Indoor Air Quality: Dampness and Moulds; WHO: Copenhagen, Denmark, 2009; pp. 31-61.

3. Highley, T.L. Biodeterioration of wood. In Wood Handbook-Wood as an Engineering Material; General Technical Report FPLGTR-113; Department of Agriculture, Forest Service, Forest Products Laboratory: Madison, WI, USA, 1999; pp. 13-1-13-16.

4. Reinprecht, L. Structural Protection of Wood. In Wood Deterioration, Protection and Maintenance; John Wiley \& Sons, Ltd.: Chichester, UK, 2016; pp. 126-144. [CrossRef]

5. Greaves, H. The bacterial factor in wood decay. Wood Sci. Technol. 1971, 5, 6-16. [CrossRef]

6. $\quad$ Eaton, R.; Hale, M.D.C. Wood, Decay, Pests and Protection, 1st ed.; Chapman and Hall: London, UK, 1993; 546p.

7. Hill, C.A.S. Wood Modification: Chemical, Thermal and Other Processes; John Wiley \& Sons, Ltd.: Chichester, UK, 2006 ; pp. 19-44. [CrossRef]

8. Goodell, B.; Qian, Y.; Jellison, J. Fungal decay of wood: Soft rot-brown rot-white rot. In Development of Commercial Wood Preservatives: Efficacy, Environmental, and Health Issues; Schultz, T.P., Militz, H., Freeman, M.H., Goodell, B., Nicholas, D.D., Eds.; American Chemical Society: Washington, DC, USA, 2008; pp. 9-31.

9. Ghosh, S.C.; Militz, H.; Mai, C. Decay resistance of treated wood with functionalised commercial silicones. BioResources 2008, 3, 1303-1314.

10. Curling, S.; Clausen, C.A.; Winandy, J.E. Relationships between mechanical properties, weight loss, and chemical composition of wood during brown rot decay. For. Prod. J. 2002, 52, 34-39.

11. Schmidt, O. Holz- und Baumpilze: Biologie, Schaden, Schutz, Nutzen. [Wood and Tree Fungi: Biology, Decay, Protection, Use]; Springer: Berlin, Germany, 1994; pp. 77-84.

12. Sutter, H.P. Holzschädlinge an Kulturgütern Erkennen und Bekämpfen. [Recognize and Combat Wood Pests on Cultural Goods]; Paul Haupt: Bern, Switzerland, 2002; 166p.

13. Robbins, C.; Morrell, J. Mold, Housing and Wood; Western Wood Products Association: Portland, OR, USA, $2002 ;$ pp. 1-7.

14. Salminen, K.; Peuhkuri, R.; Lähdesmäki, K.; Viitanen, H.; Vinha, J.; Paajanen, L.; Iitti, H.; Ojanen, T.; Strander, T. Mould growth in building materials in laboratory and field experiments. In Proceedings of the 9th Nordic Symposium on Building Physics NSB, Tampere, Finland, 29 May-2 June 2011; pp. 859-866.

15. Karlsson, O.; Yang, Q.; Sehlstedt-Persson, M.; Moren, T. Heat treatments of high temperature dried Norway spruce boards: Saccharides and furfurals in sapwood surfaces. BioResources 2012, 7, 2284-2299. [CrossRef]

16. Vidholdova, Z.; Iždinsky, J.; Reinprecht, L.; Krokošova, J. Activity of bacteria and molds on surfaces of commercial wooden composites. Mater. Sci. Forum 2015, 818, 190-193. [CrossRef]

17. Hens, H.L.S.C. Fungal defacement in buildings: A performance related approach. HVACER Res. 1999, 5, $256-280$.

18. Hukka, A.; Viitanen, H. A mathematical model of mould growth on wooden material. Wood Sci. Technol. 1999, 33, 475-485. [CrossRef]

19. Viitanen, H.; Ritschkoff, A. Mould Growth in Pine and Spruce Sapwood in Relation to Air Humidity and Temperature; Report no 221; The Swedish University of Agricultural Sciences, Department of Forest Products: Uppsala, Sweden, 1991; 49p.

20. Gorny, R.L. Filamentous microorganisms and their fragments in indoor air-A review. Ann. Agric. Environ. Med. 2004, 11, 185-197.

21. Adan, O.C.G.; Huinink, H.P.; Bekker, M. Water relations of indoor fungi. In Fundamentals of Mold Growth in Indoor Environments and Strategies for Healthy Living; Adan, O.C.G., Samson, R.A., Eds.; Wageningen Academic Publishers: Wageningen, The Netherlands, 2011; pp. 41-65.

22. Baughman, A.V.; Arens, E.A. Indoor humidity and human health-part I: Literature review of health effects of humidity-influences indoor pollutants. ASHRAE Trans. 1996, 102, 193-211.

23. Viitanen, H.; Bjurman, J. Mould growth on wood under fluctuating humidity conditions. Mater. Org. 1995, $29,27-46$.

24. Reinprecht, L.; Panek, M.; Dankova, J.; Murinova, T.; Mec, P.; Plevova, L. Performance of methyl-tripotassium silanol treated wood against swelling in water, decay fungi and moulds. Wood Res. 2013, 58, 511-520.

25. Vidholdova, Z.; Reinprecht, L.; Igaz, R. The impact of laser surface modification of beech wood on its color and occurence of molds. BioResources 2017, 12, 4177-4186. [CrossRef]

26. Myronycheva, O.; Sehlstedt-Persson, M.; Karlsson, O.; Sandberg, D. Growth of Mold and Rot Fungi on Copper-impregnated Scots Pine Sapwood: Influence of Planing Depth and Inoculation Pattern. BioResources 2018, 13, 8787-8801. [CrossRef]

27. Schultz, T.P.; Nicholas, D.D. Development of environmentally-benign wood preservatives based on the combination of organic biocides with antioxidants and metal chelators. Phytochemistry 2002, 61, 555-560. [CrossRef]

28. Kartal, S.N.; Munir, E.; Kakitani, T.; Imamura, Y. Bioremediation of CCA-treated wood by brown-rot fungi Fomitopsis palustris, Coniophora puteana and Laetiporus sulphureus. J. Wood Sci. 2004, 50, 182-188. [CrossRef]

29. Cao, Y.; Lu, J.; Huang, R.; Zhao, Y.; Wu, Y. Evaluation of decay resistance for steam-heat-treated wood. Bioresources 2011, 6, 4696-4704. 
30. Myronycheva, O.; Poohphajai, F.; Sehlstedt-Persson, M.; Vikberg, T.; Karlsson, O.; Junge, H.; Sandberg, D. Application of GRAS Compuonds for the Control of Mould Growth on Scots Pine Sapwood Surfaces: Multivariate Modelling of Mould Grade. Forests 2019, 10, 714. [CrossRef]

31. Kartal, S.N.; Hwang, W.; Imamura, Y.; Sekine, Y. Effect of essential oil compounds and plant extracts on decay and termite resistance of wood. Holz. Roh. Werkst. 2006, 64, 455-461. [CrossRef]

32. Maoz, M.; Weitz, I.; Blumenfeil, M.; Freitag, C.; Morrell, J.J. Antifungal Activity of Plant Derived Extracts against G. trabeum; No. IRG/WP 07-30433; International Research Group on Wood Protection: Stockholm, Sweden, 2007.

33. Viitanen, H.; Jämsä, S.; Paajanen, L.; Nurmi, A.; Viitaniemi, P. The Effect of Heat Treatment on the Properties of Spruce; No. IRG/ WP 94-40032; International Research Group on Wood Preservation: Stockholm, Sweden, 1994.

34. Kamdem, D.P.; Pizzi, A.; Guyonnet, R.; Jermannand, A. Durability of Heat-Treated Wood. Holz als Roh- und Werkstoff 1999, 60. [CrossRef]

35. Tjeerdsma, B.; Stevens, M.; Militz, H. Durability Aspects of Hydrothermal Treated Wood; No. IRG/WP 00-40160; Section 4-Processes; International Research Group Wood Preservation: Stockholm, Sweden, 2000.

36. Welzbacher, C.; Rapp, O. Comparison of Thermally Modified Wood Originating from Four Industrial Scale Processes-Durability; No. IRG/WP 02-40229; Section 4-Processes; International Research Group Wood Preservation: Stockholm, Sweden, 2002.

37. Esteves, B.; Pereira, H. Wood modification by heat treatment: Review. Bioresources 2009, 4, 370-404. [CrossRef]

38. Homan, W.; Tjeerdsma, B.; Beckers, E.; Jorissen, A. Structural and other properties of modified wood. In Proceedings of the World Conference on Timber Engineering, Whistler Resort, BC, Canada, 31 July-3 August 2000; p. 8.

39. Lekounougou, S.; Petrissans, M.; Jacquot, J.P.; Gelhaye, E.; Gerardin, P. Effect of heat treatment on extracellular enzymatic activities involved in beech wood degradation by Trametes versicolor. Wood Sci. Technol. 2009, 43, 331-341. [CrossRef]

40. European Standard EN 113. Wood Preservatives-Method of Test for Determining the Protective Effectiveness against Wood Destroying Basidiomycetes-Determination of the Toxic Values; European Committee for Standardization: Brussels, Belgium, 1996.

41. Crisostomo, M.C.; Del Menezzi, C.H.S. Evaluation of the Effect of Thermo-mechanical Treatment on the Resistance of Commercial OSB to Decay Fungi. Mater. Sci. 2019, 25, 190-194. [CrossRef]

42. European Standard EN 15457 (2007): Paints and Varnishes_Laboratory Method for Testing the Efficacy of Film Preservatives in a Coating Against Fungi; European Committee for Standardization: Brussels, Belgium, 2007.

43. El Abed, S.; Hamadi, F.; Latrache, H.; Iraqui, H.M.; Ibnsouda, K.S. Adhesion of Aspergillus niger and Penicillium expansumspores on Fez cedar wood substrata. Ann. Microbiol. 2010, 60, 377-382. [CrossRef]

44. Sandberg, D.; Kutnar, A.; Mantanis, G. Wood modification technologies-A review. iForest 2017, 10, 895-908. [CrossRef]

45. Tiralova, Z.; Reinprecht, L. Fungal decay of acrylate treated wood. In Proceedings of the Conference: 35th Annual Meeting IRG/WP 04-30357 The international research group on wood preservation, Section 3 Wood Protecting Chemicals, Ljubljana, Slovenia, 6-10 June 2004. [CrossRef]

46. Xiao, Z.; Xie, Y.; Mai, C. The fungal resistance of wood modified with glutaraldehyde. Holzforschung 2012, 66, 237-243. [CrossRef]

47. Boonstra, M.J.; Van Acker, J.; Tjeerdsma, B.F.; Kegel, E.V. Strength properties of thermally modified softwoods and its relation to polymeric structural wood constituents. Ann. For. Sci. 2007, 64, 679-690. [CrossRef]

48. Sivrikaya, H.; Can, A.; De Troya, T.; Conde, M. Comparative biological resistance of differently thermal modified wood species against decay fungi, Reticulitermes grassei and Hylotrupes bajulus. Maderas Cienc. Tecnol. 2015, 17, 559-570. [CrossRef]

49. Leithoff, H.; Peek, R.D. Heat treatment of Bamboo. In Proceedings of the International Research Group on Wood Preservation. Section 4. Paper prepared for the 32nd Annual Meeting, Nara, Japan, 20-25 May 2001. IRG/WP 10-40216.

50. Ayata, U.; Akcay, C.; Esteves, B. Determination of decay resistance against Pleurotus ostreatus and Coniophora puteana fungus of heat-treated scotch pine, oak and beech wood species. Maderas Cienc. Tecnol. 2017, 19, 309-316. [CrossRef]

51. Yalcin, M.; Sahin, H.I. Changes in the chemical structure and decay resistance of heat-treated narrow-leaved ash wood. Maderas Cienc. Tecnol. 2015, 17, 435-446. [CrossRef]

52. Goodell, B.; Winandy, J.E.; Morrell, J.J. Fungal Degradation of Wood: Emerging Data, New Insights and Changing Perceptions. Coatings 2020, 10, 1210. [CrossRef]

53. Curling, S.; Winandy, J.E.; Clausen, C.A. An experimental method to simulate incipient decay of wood basidiomycete fungi. In Proceedings of the International Research Group on Wood Preservation. Section 2, Test Methodology and Assessment (IRG/WP 00-20200), 31st Annual Meeting, Kona, HI, USA, 14-19 May 2000; pp. 1-12.

54. Ohno, K.M.; Clausen, C.A.; Green, F.; Diehl, S.V. Insights into the mechanism of copper-tolerance in Fibroporia radiculosa: The biosynthesis of oxalate. Int. Biodeterior. Biodegrad. 2015, 105, 90-96. [CrossRef]

55. Gadd, G.M. The geomycology of elemental cycling and transformations in the environment. In The Fungal Kingdom; ASM Press: Washington, DC, USA, 2017; pp. 371-386. [CrossRef]

56. Philp, R.W.; Bruce, A.; Munro, A.G. The effect of water soluble Scots pine (Pinus sylvestris L.) and Sitka spruce (Picea sitchensis (Bong.) Carr.) heartwood and sapwood extracts on the growth of selected Trichoderma species. Int. Biodeterior. Biodegrad. 1995, 35, 355-367. [CrossRef]

57. Xu, K.M.; Feng, J.; Zhong, T.H.; Zheng, Z.F.; Chen, T.A. Effects of volatile chemical components of wood species on mould growth susceptibility and termite attack resistance of wood plastic composites. Int. Biodeterior. Biodegrad. 2015, 100, 106-115. [CrossRef]

58. Schmidt, O.; Magel, E.; Fruhwald, A.; Glukhykh, L.; Erdt, K.; Kaschuro, S. Influence of sugar and starch content of palm wood on fungal development and prevention of fungal colonization by acid treatment. Holzforschung 2016, 70, 783-791. [CrossRef] 
59. Johansson, P.; Mjornell, K.; Arfvidsson, J. Examples of characteristics of wood that affect mould growth: A meta-analysis. Eur. J. Wood Prod. 2017, 75, 603-613. [CrossRef]

60. Feng, J.; Li, C.; Chen, J.; Chen, M.; Shu, X.; Shi, Q. Evaluation of the association between natural mold resistance and chemical components of nine wood species. Bioresources 2018, 13, 6524-6541. [CrossRef]

61. Reinprecht, L.; Vidholdova, Z.; Izdinsky, J. Bacterial and mold resistance of selected tropical wood species. Bioresources 2020, 15, 5198-5209.

62. Taylor, A.M.; Gartner, B.L.; Morrell, J.J. Heartwood formation and natural durability: A review. Wood Fiber Sci. 2002, 34, 587-611.

63. Gobakken, L.R.; Westin, M. Surface mould growth on five modified wood substrates coated with three different coating systems when exposed outdoors. Int. Biodeterior. Biodegrad. 2008, 62, 397-402. [CrossRef]

64. Anouhe, J.B.S.; Niamke, F.B.; Faustin, M.; Virieux, D.; Pirat, J.L.; Adima, A.A.; Kati-Coulibaly, S.; Amusant, N. The role of extractives in the natural durability of the heartwood of Dicorynia guianensis Amsh: New insights in antioxydant and antifungal properties. Ann. For. Sci. 2018, 75, 15. [CrossRef] 